\title{
Sustainability: Citarum River, government role on the face of SDGs (water and sanitation)
}

\author{
Resha Ayu Putri Belinawati ${ }^{1}$, Tri Edhi Budhi Soesilo $^{1}$, Donna Asteria, ${ }^{2, *}$, and Riza Harmain ${ }^{1}$ \\ ${ }^{1}$ School of Environmental Science, Universitas Indonesia, Salemba, Indonesia \\ ${ }^{2}$ Communication Department, Faculty of Social and Political Science, Universitas Indonesia, Depok, \\ Indonesia
}

\begin{abstract}
Citarum River is one of the most polluted river in the word. The pollution is not only derived from plant waste, but also household waste to livestock. West Java Government has a policy to handle Citarum problems, called Citarum Bestari Program. Citarum Bestari expected to solve pollution problems in Citarum River. This paper seeks to attempt the position of the West Java Government policy in the face of SDGs, particularly in this research will using qualitative methods, which is supported by the concept of David Easton political system. The author would like to see any input that may affect the policy-making in the local government with a political ecology approach. Support and demand for local governments of West Java is quite a lot already, not only from the international community but also among local residents and NGOs. This happens because many environmental impacts that occurred lately, such as flooding. Pollution that occurred along the Citarum River should be of particular concern for the Government of West Java, takes a neutral policy and strict supervision. Not only policies that benefit one of the parties (producers) but also to the other party (the environment and society).
\end{abstract}

\section{Introduction}

The high population and economic growth in Indonesia, especially in West Java has become the full attention of the Regional Government of West Java. However with the high population growth in West Java has not been balanced with good facilities and infrastructures. It is proven by the position of the Citarum River that became one of the 10 most polluted rivers in the world [1].

Issues about the Citarum River and SDGs is not the first time discussed, there have been many studies about Citarum River and the connection to the SDGs especially for water and sanitation, as well as the local governments awareness and need to execute programs based on the SDGs. This has been highly documented. Some examples about SDGs: "Sustainable Development Goals (SDGs) to be successful, a major shift in conceptual thinking about water management is needed. It must be recognized that there is no single approach for sequencing portfolios of investment to improve water security and that a high degree of flexibility will be needed to embrace the unique economic, social and environmental

* Corresponding author: donna@ui.ac.id 
circumstances that will determine a nation's pathway towards water security and prosperity" [2] and the key success of water and sanitation goals is "indicators for this target are defined and monitored will be key to ensuring that resources are most effectively deployed to benefit those currently without access to safe drinking water" [3]. There are also some example about The Citarum River: "Citarum River has been damaged and polluted heavily by sediments and various wastes Therefore it is necessary to formulate an environmental management strategies and technologies to rehabilitate the Citarum River so that its role can be sustained" [4].

The Citarum River is a watershed (river) longest in western Java. The length of coverage Citarum River is also divided into three parts: Indonesia the Citarum River catchment occupies an area of approximately $7400 \mathrm{~km} 2$, which can be divided into three parts; upper $\left(1771 \mathrm{~km}^{2}\right)$, middle $(4242 \mathrm{~km} 2)$ and lower $\left(1387 \mathrm{~km}^{2}\right)$ [5]. Citarum River can be seen also the streams of Citarum. Along Citarum River, there are 3 major dams, there are: Saguling, Cirata and Jatiluhur, storage dams were built on this river and are used for hydropower, irrigation, water supply [6].

The data from the Black Smith Institute and Green Cross Switzerland in 2013 showed that Indonesia referred one of 10 countries that have the most polluted rivers in the world and the Citarum River is one of them. Citarum River pollution is not just at one point but have occurred along the Citarum River from upstream to downstream. Sources of problems that occur in the upper Citarum River are dominated by the public and government low concern about the preservation of nature. Some problems can be formulated as follows [7]:

1. The shift area protected areas (forest and non-forest) into residential areas, agriculture, and industry.

2. The increase in the number of critical land area as a result of planning and poor supervision, 3. pollution of rivers by domestic waste, is waste water originating from settlements, agriculture, and industry

3. The level of groundwater out of control (exploited excessively) causing subsidence and increase the potential of flood-prone areas.

The other data identify the problems of Citarum River, there are:

Table 1. Identification of Citarum River problems [5].

\begin{tabular}{|l|l|}
\hline \multicolumn{1}{|c|}{ Citarum River Problems } & Resolved/Not \\
\hline Industrial Waste Pollution & Not Resolved \\
\hline Livestock / Livestock Waste Dissemination & Not Resolved \\
\hline Domestic waste contamination (household waste) & Not Resolved \\
\hline Change of Land Use and Critical Land & Not Resolved \\
\hline Changes in Community Behavior & Not Resolved \\
\hline Damage / Reduction of Water Sources & Not Resolved \\
\hline Law Enforcement & Not Resolved \\
\hline
\end{tabular}

Pollution coming from this household is quite dominant considering the number of human population living along the river Citarum is increasing. One of them is cooking oil, which comes from palm oil. The contribution given by cooking oil in the contamination of the Citarum River is $(0.1 \%)$ [8].

The impact from polluted Citarum River are; they will lose their livelihood. West Java government should play an active role in addressing the problems Citarum River. This is already become a concern for the Government of West Java. in 2015 West Java Government have a program called "Citarum Bestari". Provincial Government of West Java (West Java Government) issued Governor Regulation No. 78 Year 2015 is Citarum Bestari (Bersih : Clean, Sehat : Healthy, Indah : Beautiful, and Lestari : Lestari). Citarum Bestari is expected to be a solution for the West Java government in facing pollution that occurred along the Citarum River, because the pollution that occurs is quite heavy. 
The return of watershed functions is also supported by the agreement of countries that have participated in the signing of SDGs (Sustainable Development Goals). SDGs has 17 Goals, these goals support to meet the overall objectives of SDGs. SDGs has a time period of up to 2030 where each country must reach before the year is reached. The purpose of SDGs No. 6, specifically discusses water and sanitation. The big goals from SDGs 6 Water and sanitation is "ensuring that communities have access to clean water". One of these indicator from the goals is to reduce pollution and reduce the amount of waste disposed into the river. Problem about water and sanitation is become important because, the growing global population requires ever- larger quantities of food, energy, and other resources, which must be met by agricultural, economic, and infrastructure systems already straining planetary boundaries [9]. Water and sanitation is one of the SDGs goals, goals number 6.3 is: Ensure availability and sustainable management of water and sanitation for all [10]. The SDGs for water and sanitation are mentioned indirectly but have considerable coverage.

\section{Material and methods}

In this study, the authors would to see how the SDGs can influence the policy and how policy can support the Local Government goals for SDGs 2030. In this study the authors would use a qualitative approach. The authors would like to see how the symptoms, events and facts to form a conclusion. Also in this study the researchers also used the approach to environmental science. [11] Approach to environmental science is a science that integrates the natural sciences, social and holistic studies around us.

The authors would looking at how the position of the West Java Government in achieving SDGs. In particular for the water and sanitation (point 6.3) focus on reducing toxic waste into rivers and households. The author would see in terms of policy making, which the policies made by the Government of West Java is in conformity with these achievements without prejudice to sustainability and environmental concepts.

\subsection{Sustainability concept}

Sustainability is the ability of the earth and the human nature to survive, develop, and adapt to changing environmental conditions in the long term [12]. According to Engger \& Smith is an act of sustainable development to meet the needs of the present without compromising the ability of future generations to meet the needs of life on Earth's renewable resources without destroying the ecological processes that support [13]. According to (IUNN/UNEP/WWF) Sustainable development is to improve the quality of life, without damaging nature.
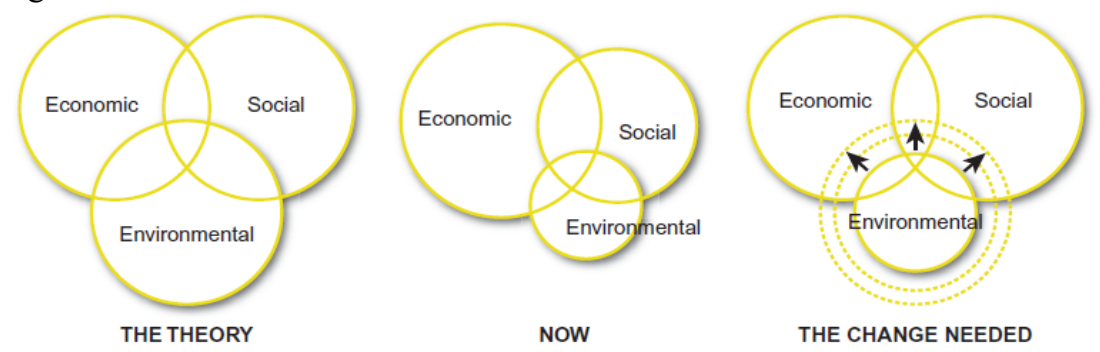

The three pillars of sustainable development, from left to right; the theory, the reality and the change needed to better balance the model

Fig. 1. Sustainable development [14]. 
From figure 1, the concept of sustainable development is given the IUCN explained that the environmental aspects should be included in the social and economic aspects. This happens because nowadays the environmental aspects tend to be excluded. Indonesia is a developing country, the type of developing countries is to improve the infrastructure, without looking at the environmental aspects. It should not have happened, because aspects of environmental, economic and social have the same parts. Sustainable development is agreed upon as a development that meets the needs of the present without sacrificing the right to meet the needs of future generations. It contains two important ideas: (a) the idea of "necessity" that is essential to sustain human life, and (b) the idea of limitations that stem from technological conditions and social organization's environmental capacity to meet present and future needs [15].

\subsection{Political systems theory David Easton}

David Easton's systems theory is a simple way to see a political system starting from how the proposed policy as a policy makers and how it will impacts to the community. in Figure 2 shows that the policy has born because there is a support in the environment and the demands of the society. Then they processed in a policy process, and generate a policy, but it does not stop in a policy, we would like to see the impact of the policies to the public, which made by the Government. According to Easton outside and behind the political system there is other systems or the environment, either physical, biological, social, psychological and so that could be the cornerstone of distinguishing between the political systems with the system eat it [16]. Easton views political life as a system consisting of interrelated activities. The activation finds its systemic relationships or links from the fact that they affect how an authoritative decision is formulated and implemented. If political life is viewed as an activity system, then there is a certain consequence of how to conduct an analysis of the operation of a system [17]. In this study the authors will looking at the factors that influence the local government of West Java in creating policies that correspond to the achieve of SDGs. The author would like to see the input factors and the process, and how they impact the local government of West Java.

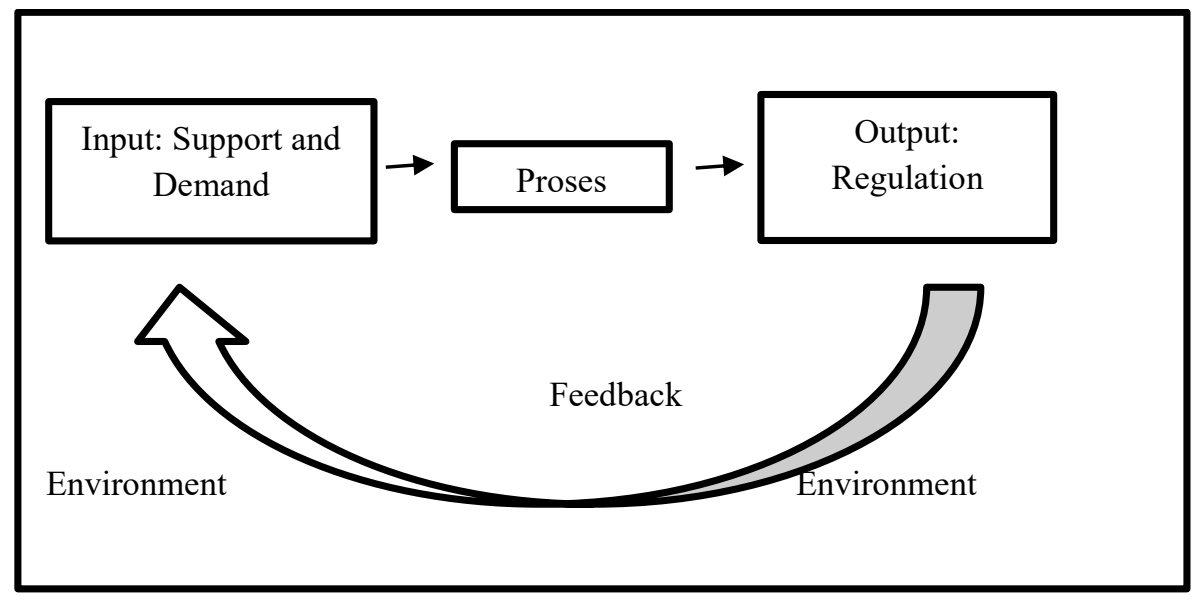

Fig. 2. Political systems theory David Easton 


\section{Result and discussion}

Figure 3 illustrates that the inputs of this demand and support have a large effect on processes and outputs. Currently Indonesia is faced with several demands such as SDGs that have started running and must be achieved in the know 2030, the economic needs and human needs. To fulfil the whole, the Indonesian government must prepare the appropriate policy. This is done so as not to focus on one goal of the economy. The sources of the contaminants come from various kinds: industrial waste, household waste (plastic, cooking oil) contribute to water pollution especially in West Java. To handle it eat though on-stage process and out program that handling pollution problem of Citarum River.

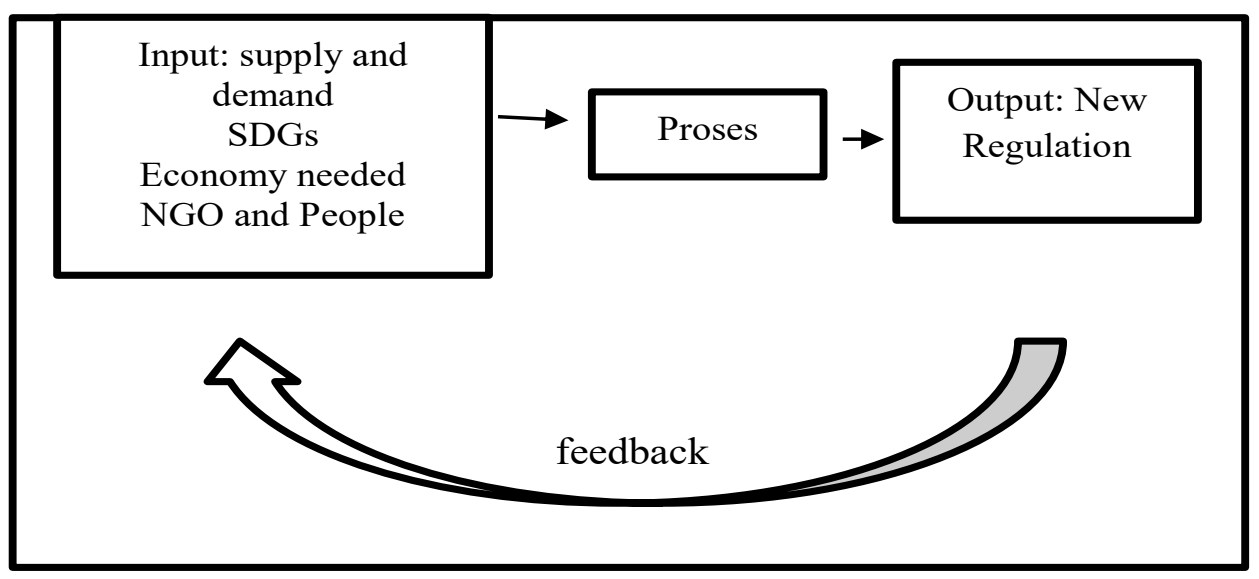

Fig. 3. Implementation of Political Systems Theory David Easton with the case

Sustainable development is a major challenge for Word country, and as the action the make a regulation to solve the issue/problem, called SDGs. Indonesia, is one of the word country need to achieve the goals, in West Java Government (Indonesia) is faced with a major problem that is polluted in Citarum River. This is of particular concern for local governments because current West Java West Java Government are faced with the new goal, there is: SDGs. That is a continuation of the MDGs. When the MDGs era, West Java Government has a program to settle the problems of the Citarum River, called Citarum Bestari. However, to achieve the goals of the SDGs, West Java Government need a new strategy to solving those problems. Because the previous program was made for the MDGs, is not change a lot of Citarum River condition.

Policy-making based on supply and demand, which the West Java Government was faced with the demands of SDGs. In SDGs the function of Central Government dis controlling, because the scheme used in SDGs is the contribution of local government to meeting these goals. In the previous, Government of West Java also has a program called Citarum Bestari. Currently the West Java Government must move fastest in resolving this issue. The theory of David Easton's political system help to understand how the the government make a policies/regulation. The demands is not only from the SDGs, but also from communities and NGOs, surrounding communities assisted by NGOs pushing West Java Government to make a policy in addressing the problems of the Citarum River. In the case of the Citarum River catcher the input of experts is needed, not only from environmentalists but from social and economic experts as well. The government needs to hear the advice and input that experts provide, for better Citarum purposes [18]. 


\section{Conclusion}

Policies are made by the West Java local government cannot be separated from demands and support. The Demands not only politically issue but also ecological and economic. From the Politics: Government of Indonesia in this case the Government of West Java should meet the objectives of the SDGs, as it will improve the bargaining position of Indonesia in the international world, especially in achieving the SDGs Goals 6.3 (water and sanitation), from an economic standpoint: economic development is still necessary for local residents, pollution is happening currently profitable one, but harmful to the other, such as waste disposal textile, household waste and others, will have an impact there irrigation for farmers along the Citarum River, in terms of ecology, flood already widely occurred in West Java not only that access to clean water is also reduced, which before the residents rely on water from the Citarum River, and now, they didn't use that, because the water conditions are not suitable for consumption.

\section{Acknowledgements}

This research is funded by the Grant of Indexed International Publication for Final Project of Students/Publikasi Terindeks Internasional Untuk Tugas Akhir Mahasiswa (PITTA) Universitas Indonesia 2018 with contract number 2579/UN.R3.1/HKP.05.00/2018

\section{References}

1. Blacksmith Institute And Green Cross Switzerland. The worlds worst 2013, the top ten toxic threats cleanup, progress, and ongoing challenges. (2013)

2. M. Ait-Kadi. Water for development and development for water: realizing the Sustainable Development Goals (SDGs) Vision. Aquatic Procedia 6, (2016)

3. G.Y. Soetrisno. status and characteristics of pollution in the Citarum Cascade Reservoir. Journal of Environmental Technology 2, 2 (2001)

4. I. Juwana, N. Muttil, B.J.C. Perera. Uncertainty and sensitivity analysis of West Java Water Sustainability Index - A case study on Citarum catchment in Indonesia. Ecological Indicators 61, (2016)

5. Kurniasih, N. Journal of Environmental Technology, 5 (2002).

6. K. Noda, K. Yoshida, H. Shirakawa, U. Surahman, K. Oki. Effect of land use change driven by economic growth on sedimentation in river reach in Southeast Asia. Journal of Agricultural Meteorology 73, (2017)

7. T.F. Sabrina, M. Halimi, \& K. Komalasari. Implementasi Gerakan Citarum Bestari (GCB) dalam menumbuhkan civic responsibility terhadap lingkungan. Jurnal Civicus 20, (2016)

8. J.T. Trimmer, R.D. Cusick, J.S. Guest. Amplifying progress toward multiple development goals through resource recovery from sanitation. Environmental Science and Technology 51, (2017)

9. D. Satterhwaitte. A new urban agenda? Environment and Urbanization 18, (2016)

10. P. Thomsona, J. Koehlera. Performance-oriented monitoring for the water sdg challenges, tensions and opportunities. Aquatic Procedia 6, (2016)

11. W.P. Cunningham, M.A. Cunningham. Environmental Science: A Global Concern, 12th ed. (McGraw-Hill, New York, 2012)

12. G.T. Miller, S. Spoolman. Environmental Science (Cengage Learning, Boston, 2014) 
13. E. Engger, B.F. Smith. Environmental Science: A Study of Interelationship 12th ed. (McGraw-Hill, New York, 2010)

14. The IUCN Programme 2005_2008: Many voices, one Earth, adopted at the World conservation Congress, Bangkok, Thailand, 17-25 November 2004

15. Akhmad, F., Alex, O. Journal of Development Economics 15, (2014)

16. Solong, H. A. Read Journal 8, (2015).

17. Magriasti, L. Proceeding the National Symposium on Regional Autonomy (2011).

18. A. Brotosusilo, D. Utarai, A.A. Satria. Sustainability of water resources in the upstream watershedbased community engagement and multistakeholder cooperation. IOP Conference Series: Earth and Environmental Science 30 012018, (2016) 